\title{
A VAJDASÁGI MAGYAR AJKÚ FIATALOK SZABADIDŐS TEVÉKENYSÉGE
}

\author{
Szerzők: \\ Borsos Éva (PhD.) \\ Újvidéki Egyetem Magyar Tannyelvú \\ Tanítóképző Kar (Szerbia) \\ Horák Rita \\ Újvidéki Egyetem Magyar Tannyelvű \\ Tanítóképző Kar (Szerbia) \\ Első szerző e-mail címe: \\ bborsos@gmail.com
}

\author{
Lektorok: \\ Mező Katalin (PhD.) \\ Debreceni Egyetem (Magyarország) \\ Mező Ferenc ( $\mathrm{PhD}$.) \\ Eszterházy Károly Egyetem(Magyarország) \\ ...és további két anonim lektor
}

Borsos Éva, Horák Rita (2021). A vajdasági magyar ajkú fiatalok szabadidős tevékenysége. Különleges Bánásmód, 7. (3). 95-99. DOI 10.18458/KB.2021.3.95

\begin{abstract}
Absztrakt
Napjainkban az emberek életmódját többnyire a helytelen táplálékbevitel és a mozgásszegény életmód jellemezi. Különösen nagy figyelmet kell erre fordítani gyermekkorban, hiszen a gyerekek szokásai ilyenkor még alakíthatók. A gyermekek fejlődés szempontjából is meghatározó, hogy helyesen és egészségesen táplálkozzanak-e és, hogy rendszeresen végezzenek-e testmozgást. A kutatásban általános iskolás gyerekek tápláltsági állapotát határoztuk meg, valamint a PAQ-C (physical activity questionnaire) kérdőív segítségével a fizikai aktivitásukat is felmértük. A kutatás részeredményei azt mutatják, hogy a fiúk között több a túlsúlyos, még akkor is, ha ôk sportolnak többet rendszeresen és az órák közötti szünetekben is ők az aktívabbak. A sportok közül a fiúknál a labdarúgás a lányoknál a kosárlabda dominál. A tanulmány a 142-451-2637/2019-01 vajdasági tartományi projektum keretein belül végzett kutatás rész eredményeit mutatja be.
\end{abstract}

Kulcsszavak: fizikai aktivitás, gyerekek, sport, tápláltsági állapot

Diszcilina: sporttudomány

\section{Abstract \\ HUNGARIAN YOUNG PEOPLE'S FREE TIME ACTIVITIES IN VOJVODINA}

Nowadays the lifestyle of most people is characterised by improper food intake and by a sedentary lifestyle. Especially in childhood, great attention should be paid to this, because children's habits can be formed at this age and for their development it is very important to eat properly and healthy and to exercise regularly. During the research, elementary school children's nutritional status was determined and their physical activity was measured using the PAQ-C (physical activity questionnaire) questionnaire. The partial results of the research show that among boys there are more overweight person, even so they do 
more sports regularly and they are more active during breaks between classes. Among sports the football is dominant in the case of the boys and the basketball is dominant in the case of the girls.

The work presented partial results of the research carried out during the Vojvodina provincial project 142451-2637/2019-01.

Keywords: physical activity, children, sport, nutritional status

Discipline: sport science

A XXI. század egyik jelentős problémája, hogy a gyerekek a szabad idejük nagyrészét a számítógép előtt töltik és ennek következtében keveset mozognak. A mozgásszegény életmód számos negatív egészségkárosító következménnyel jár. Az egészség fogalmát a WHO a következőképpen határozta meg: „Az egészség a teljes testi, lelki és szociális jólét állapota, és nem csupán a betegség vagy a fogyatékosság hiánya." A testmozgás éppen a lelki egészséget és az egészséges személyiségfejlődést szavatolja.

A gyermekkori elhízás legfőbb okai az egészségtelen táplálkozás és a mozgás szegény életmód. A mozgásigény kialakítása nagyon fontos, hiszen kihatással van a gyermek egészséges fejlődésére. A rendszeres mozgás elősegíti, hogy a testarányok és a testsúly megfelelően alakuljon. A fizikai aktivitás elősegíti a betegségek elkerülését és a lelki állapotunkra is jó hatással van (Hidvéghi et al., 2015). Az elhízottság az utóbbi 15-20 év alatt szinte már világjárvánnyá nőtte ki magát (Söderlund et al., 2009). Egyes kutatások szerint (Török, 2001) a tanulók több mint 90\%-ánál a leggyakoribb időtöltés a tévénézés, az olvasás, a számítógéphasználat, azonban figyelemre méltó, hogy a legnépszerűbb tevékenységformák között megtalálható a sport is.

Egy 2000-ben elvégezett kutatás szerint Szerbiában a felnőtt lakoság több mint 55\%-a küzd súlyproblémákkal (Zavoda za zaštitu zdravlja Srbije - Szerbiai Egészségügyi Intézet, 2000). Ebből 36,7\% túlsúlyos 17,3\% pedig elhízott (Petrov et al.
2010). Hasonló eredmények jelentek meg, a magyarországi adatokban is. A magyarországi adatok szerint is nő az elhízott gyerekek száma, még az 1970-es években a gyerekek 7-9\%-a volt túlsúlyos, mára ez a szám 12-18\%-ra emelkedett. Ennek részben oka a nem megfelelő táplálkozás is különösképpen a gyorsételek veszélyesek ilyen szempontból (Barabás, 2006). Az elhízásra akkor kerül sor, ha több energiát viszünk be a szervezetünkbe, mint amennyit el tudunk használni. A szakirodalom szerint az elhízás a zsír felhalmozódását jelenti a test különböző részein, melynek következtében cukorbetegség, magas vérnyomás és agyvérzés vagy infarktus is bekövetkezhet (Pintér, 1991).

A testtömeg index segítségével (BMI) ki lehet számítani az egyén BMI-jét és meg lehet állapítani hogy a testsúlya megfelelô-e, de az ideális testsúlyt is meg határozhatjuk (Cui et al., 2016). A BMI-t úgy számoljuk, ki, hogy a testsúlyt (kg-ban kifejezve) elosztjuk a méterben kifejezett testmagasság négyzetre emelt értékével.

$$
\mathrm{BMI}=\frac{\text { testsúly }(\mathrm{kg})}{\text { testmagasság }(\mathrm{m})^{2}}
$$

Az elhízást és az elhízás következményeit kiküszöbölhetjük, ha már gyerekkorban a gyerekeket az egészséges életmódra neveljük. Ebben különösen fontos szerep jut az iskoláskor előtti intézményekben dolgozóknak (Hipel et al., 2007). 
Az egészséges életmódhoz hozzátartozik a sportolás is. A sport kiválasztására több tényező is hat: a sportág népszerúsége, a gyermek aktuális kívánsága, hogy hova járnak társai, a véletlen, a klubok földrajzi elérhetősége, a szülők (meg nem valósult) vágyai. Kutatásunkban az általános iskolások tápláltsági állapotával és fizikai aktivitásával foglalkozunk. Jelen munkában a kutatás részeredményeit közöljük.

\section{Módszer}

A viasgálat célja

1. az általános iskolás gyerekek tápláltsági állapotának vizsgálata: testmagasság testsúly mérés

2. az általános iskolás gyermekek fizikai aktivitásának vizsgálata: fizikai aktivitás (PAQC) kérdőív segítségével

\section{Anyag és módszer}

A felmérést vajdasági általános iskoláskorú (6-15 év) gyerekek körében végeztük el $(\mathrm{n}=120)$. Az eredmények kielemzése még folyamatban van, ezért a jelenlegi munkánkban csak részeredményeket mutatunk be: tíz véletlenszerúen kiválasztott fiú és tíz lány testsúly adatait és szabadidős fizikai aktivitásaival kapcsolatos véleményét elemeztük ki.

A vizsgált lányok közül egy-egy 7 illetve 9 éves. Hárman-hárman a 10 illetve a 13 éves korosztályhoz tartoznak. A legidősebb lány, pedig 14 éves (1.ábra).

\section{1.ábra: A lányok életkora (forrás: szerzőo)}

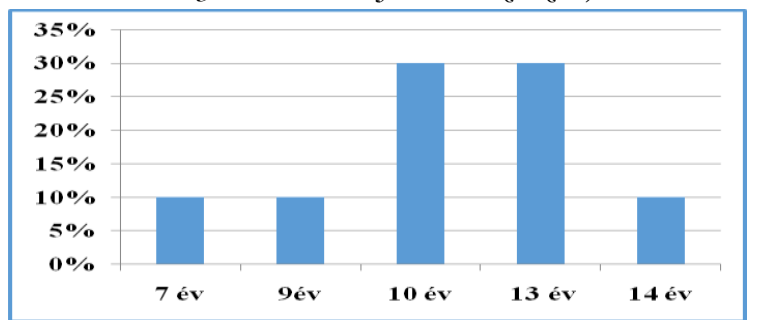

A fiúk életkora is hasonló eloszlást mutat (2. ábra). Egy fiú 7 éves. Ketten- ketten a 8 illetve a 9 éves korosztályhoz tartoznak. A 11 éveseket is egy személy képviseli. A 13 évesek korcsoportjából, pedig négy egyén adatait mutatjuk be.

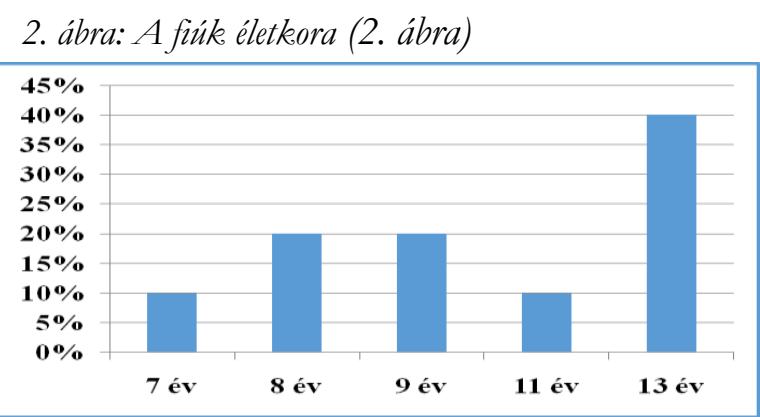

A testmagasság mérése antropométerrel, a testsúly mérése pedig tudományos kutatásokra hitelesített mérleggel történt. A testsúly és a testmagasság adatok alapján kiszámoltuk a percentilis értékeket és a nemzetközileg elfogadott táblázatokból kikerestük, hogy melyik tanuló, melyik kategóriába tartozik: sovány, normális a testsúlya, súlyfeleselege van, vagy túlsúlyos.

A fizikai aktivitás felmérése a szakirodalomban széleskörűen használt fizikai aktivitás kérdőív: PAQ-C (physical activity questionnaire for children) segítségével történt, melyet a tanulók önállóan töltöttek ki.

\section{Eredmények}

A percentilis értékek alapján a felmérésben szereplő tanulókat négy különböző testsúly kategóriába tudtuk besorolni: sovány, normális testsúlyú, súlyfelesleggel rendelkező és túlsúlyos. A lányok testsúly kategóriáit a 3. ábra mutatja be. Ketten a sovány csoportba kerültek a testsúlyuk és a testmagasságuk illetve az életkoruk alapján meghatározott percentilis érték alapján. Többségük (4 fő) normális testsúlyú. Két tanuló súlyfelesleggel rendelkezik. Két fó pedig már ebben a korban túlsúlyosnak számít (3.ábra) 
3. ábra: A lányok testsúlya (forrás: szereơók)

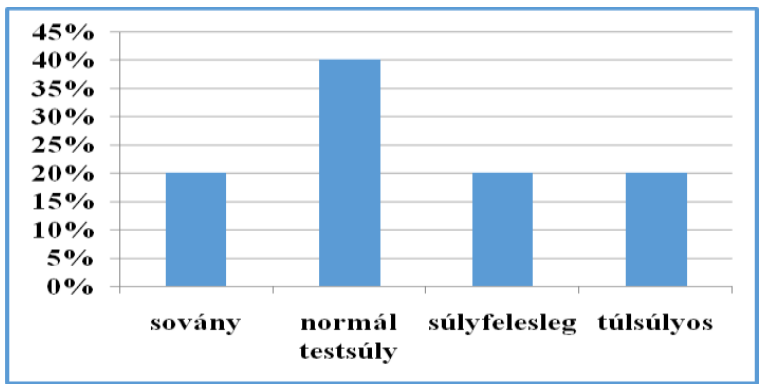

A felmérésben szereplő fiúk testsúly adatait a 4 . ábra szemlélteti. Egy fiú a sovány csoportba került. A fiúk esetében is a többségük testsúlya életkoruknak és testmagasságuknak megfelelően normálisnak tekinthetó (4 személy). Azonban a fiúk esetében is ketten súlyfelesleggel rendelkeznek, hárman a túlsúlyos kategóriába kerültek.

\section{4. ábra: A fiúk testsúlya (forrás: szerzớk)}

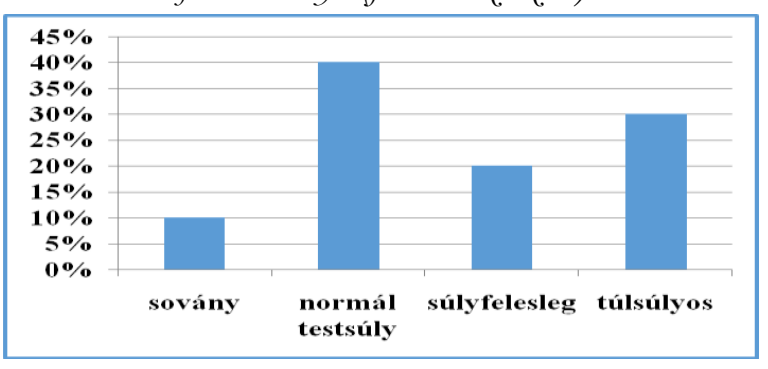

A tanulóknak a kérdőívben meg kellett jelölniük, hogy milyen sporttal foglalkoznak rendszeresen. A lányok esetében 4-en a „semmi” válasz lehetöséget választották. Ketten kosárlabdaedzésekre járnak. Egy-egy tanuló, pedig úszással, asztalitenisszel, atlétikával illetve tánccal foglalkozik.

A fiúk esetében nagyon jó eredménynek számít, hogy a vizsgálatban résztvevő tanulók közül mindenki foglalkozik valamilyen sporttal, fizikailag aktív. A legnépszerúbb a labdarúgás, 6 fiú is ezt jelölte meg. A második helyre a boksz került (2 fő). Jégkorongedzésekre egy fiú jár. Van egy olyan fiú is, aki a boksszal és az úszással is szívesen foglalkozik szabad idejében.
Arra is kíváncsiak voltunk, hogy a tanulók saját bevallásuk szerint mennyire voltak aktívak az elmúlt hetek testnevelés óráinak alkalmával. A tanulók a „szinte soha”, a „néha”, a „gyakran” és a „mindig” válaszlehetôségek közül tudtak megjelölni egyet. Ezen kérdés esetében is külön kielemeztük a lányok és külön a fiúk véleményét.

A lányok közül senki nem volt felmentve, mindenki tornázott az iskolában az elmúlt időszakban. A négy-négy lány úgy gondolja, hogy „mindig” illetve ,gyakran” volt aktív a testnevelés órák során. Egy lány véleménye az, hogy csak néha aktív ezeken a tanítási órákon. Egy fő pedig saját bevallása szerint szinte soha nem aktív a sporttal foglalkozó órákon. A fiúk ebben a kérdésben is eredményesebbnek és aktívabbnak bizonyultak, közülük sem volt senki felmentve. A fiúk többsége a „mindig aktív voltam” választ adta. Második helyre került a "gyakran" voltam aktív vélemény (3 személy). Két fiú gondolta úgy, hogy ők csak néha voltak aktívak az elmúlt heti testnevelés órák során.

$\mathrm{Az}$ utolsó feldolgozott kérdésben pedig arról érdeklődtünk a tanulóknál, hogy mit csinálnak az óraközi nagy szünetekben. A felkínált válaszok: „ültem”, „sétáltam”, „futkároztam”, „sokat futkároztam” és „főleg futkároztam”. Nagy örömünkre szolgált, hogy egyikük se jelölte be az „ültem” lehetőséget. A lányok többsége sétált az óraközi szünetben (6 válasz). Ketten a „futkároztam” lehetőséget kari-kázták be. Egy személy úgy gondolja, hogy ő sokat futkározott, egy pedig úgy, hogy ő főleg futkározott (5. ábra).

A fiúk ebben a tekintetben is aktívabbnak bizonyultak (6. ábra). A legtöbben a ,sokat futkároztam" lehetőséget jelölték meg (4 válasz). Ketten a főleg futkároztak az óraközi szünetekben. Ketten úgy gondolják, hogy nem csak futkározással foglalkoznak ebben az időszakaszban és ketten pedig sétálással töltik az óraközi szüneteket 
5. ábra: A lányok óra közi aktivitása. Forrás: Szeroőo.

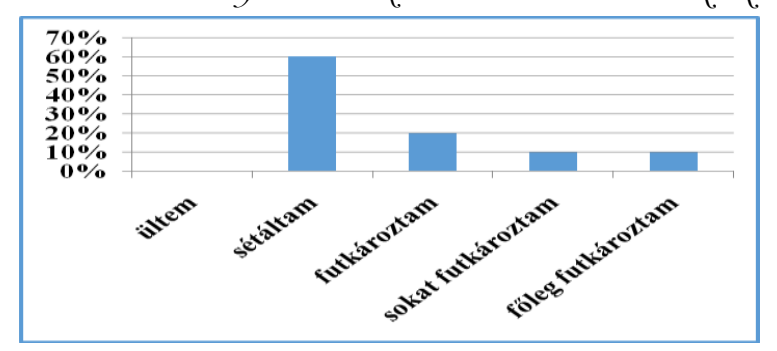

6. ábra: A fiúk óra közi aktivitása. (Forrás: Szerzọö)

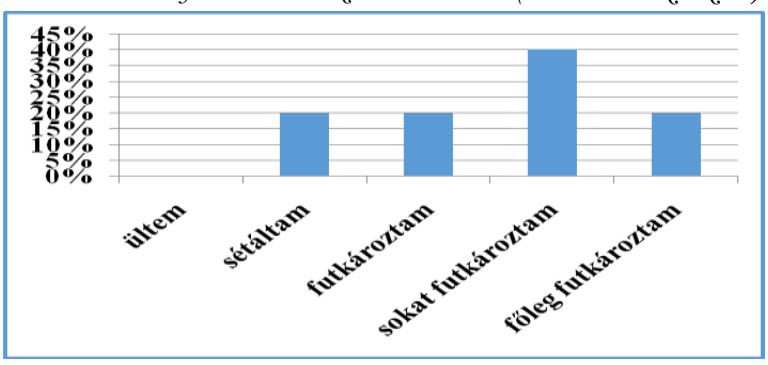

\section{Következtetések}

Jelen tanulmány csak a felmérés részeredményeit mutatja be, így se messzemenő következtetéseket, sem szakirodalmi összehasonlítást nem tudunk még elvégezni. Néhány dolog azonban, már a feldolgozott adatok alapján is megállapítható:

- A fiúk között többen a túlsúlyososak.

- A fiúk közül többen sportolnak rendszeresen.

- Saját bevallásuk szerint tornaórán nagyjából egyformán aktívak a lányok és a fiúk.

- Saját bevallásuk szerint az óraközi szünetekben a fiúk aktívabbak, mint a lányok.

Az eredményekből egyértelműen kiderül, hogy folytatni kell az eredmények feldolgozását és levonni a végső következtetéseket. A gyermekkori elhízásról nem lehet eleget beszélni, hiszen egy folyamatosan fennálló problémáról van szó, amelynek igen súlyos következményei, szövődményei lehetnek felnőtt korban. A másik kulcskérdés, pedig a gyerekek szabadidős fizikai aktivitása, ami szintén nagymértékben hozzájárul megfelelő, egészséges fejlődésükhöz.

\section{Irodalom}

Barabás, K. (2006). Egésæségéfejlesztés. Medicina Könyvkiadó Rt, Budapest.

Cui, Z., Stevens, J., Truesdale. P. K., Zeng, D., French, S., Gordon-Larsen, P. (2016). Prediction of Body Mass Index Using Concurrently Self-Reported or Previously Measured Height and Weight. PLoS One, 11(11), 1-10. doi 10.1371/journal.pone.0167288

Hippel, T. P., Powell, B., Downey, B. D., Rowland, J. N. (2007). The Effect of School on Overweight in Childhood: Gain in Body Mass Index During the School Year and During Summer Vacation. American Journal of Public Health, 97(4), 696-702.

Hidvégi, P., Kopkáné Plachy, J., Müller, A. (2015). Az egészséges életmód. Eszterházy Károly Főiskola Sporttudományi Intézet Eger.

Petrov, B., Stevanović P. S., Paunović K. (2010). Biológia az általános iskolák 7. osztálya számára. Zavod za udžbenike, Beograd

Pintér, A. (2004). Útmutató és táblázatok a gyermekekori tápláltság megitéléséhez, Magyar Védőnők (MAVE 1991) Kiadó, Budapest.

Söderlund, A., Fischer, A., Johansson, T. (2009). Physical activity, diet and behaviour modification in the treatment of overweight and obese adults: a systematic review. Perspectives in Public Health, 129, 1132-1142. doi $\underline{10.1177 / 1757913908094805}$

Török, B. (2009). Számítógép-használat óvodáskorban - az országos szülővizsgálat eredményei alapján. https://ofi.oh.gov.hu/torok-balazs-szamitogephasznalat-ovodaskorban-az-orszagosszulovizsgalat-eredmenyei-alapjan letöltve: 2020.04.29. 